\title{
Wingless-type inducible signaling pathway protein-1 inflammation, diabetes and aging
}

\author{
Natalia Nikolaevna Rudovich \\ Hospital of Bülach, Bülach, Switzerland; Associated Professor of Charité - Medical University Berlin, Germany \\ natalia.rudovich@spitalbuelach.ch
}

\begin{abstract}
Obesity is a growing global health issue linked to the development of type 2 diabetes and other aging associated conditions like cancer and neurocognitive disorders. Adipose tissue dysfunction results in altered adipokine secretion, lowgrade inflammation and ectopic fat accumulation. Recently, our group identified Wnt1-inducible signaling pathway protein-1 (WISP-1) as a multifunctional factor in inflammatory and fibrotic processes in a cell-context-specific role.
\end{abstract}

\section{Keywords - aging, inflammation, obesity, type 2 diabetes}

Obesity is a growing global health issue linked to the development of type 2 diabetes and other aging associated conditions like cancer and neurocognitive disorders [1]. Adipose tissue dysfunction results in altered adipokine secretion, low-grade inflammation, and ectopic fat accumulation [2]. Recently, our group identified Wnt1inducible signalling pathway protein-1 (WISP-1 or CCN4) as inflammatory adipokine, which supress insulin signalling in muscle cells and hepatocytes, contributing to obesity and associated diseases [3-5]. In further studies, a correlation between WISP-1 and body weights as well as metabolic parameters such as fasting glucose and insulin levels in gestational diabetes and type 2 diabetes was described [5-7]. In addition, recent studies suggest possible effects of circulating WISP-1 on fat cell differentiation in animals [8]. The underlying mechanisms still need clarification and are currently investigated. In humans, the expression of WISP-1 in the visceral adipose tissue and liver positively correlated with the body mass index $[3,7]$. An association of WISP-1 with inflammatory markers and transforming growth factor- $\beta$ in humans and mice was demonstrated [9]. Furthermore, recently published data links WISP-1 to fibrosis in different tissue [9-13]. In contrast, WISP1 is required for efficient muscle regeneration and loss of WISP1 during aging contributes to age-related regenerative failure of skeletal muscle [14]. Taken together, WISP-1 is a multifunctional factor in inflammatory and fibrotic processes in a cell-contextspecific role. Based on recently findings, WISP-1 is a promising target for future research studies in the field of obesity, fibrosis and ageing

\section{REFERENCES}

[1] Mokdad, A. H., E. S. Ford, B. A. Bowman, W. H. Dietz, F. Vinicor, V. S. Bales \& J. S. Marks (2003) Prevalence of obesity, diabetes, and obesity-related health risk factors, 2001. JAMA, 289, 76-9.

[2] Gregor, M. F. \& G. S. Hotamisligil (2011) Inflammatory mechanisms in obesity. Annu Rev Immunol, 29, 415-45.

[3] Murahovschi, V., O. Pivovarova, I. Ilkavets, R. M. Dmitrieva, S. Docke, F. Keyhani-Nejad, O. Gogebakan, M. Osterhoff, M. Kemper, S. Hornemann, M. Markova, N. Kloting, M. Stockmann, M. O.
Weickert, V. Lamounier-Zepter, P. Neuhaus, A. Konradi, S. Dooley, C. von Loeffelholz, M. Bluher, A. F. Pfeiffer \& N. Rudovich (2015) WISP-1 is a novel adipokine linked to inflammation in obesity. Diabetes, 64, 856-66..

[4] Horbelt, T., C. Tacke, M. Markova, D. Herzfeld de Wiza, F. Van de Velde, M. Bekaert, Y. Van Nieuwenhove, S. Hornemann, M. Rodiger, N. Seebeck, E. Friedl, W. Jonas, G. H. Thoresen, O. Kuss, A. Rosenthal, V. Lange, A. F. H. Pfeiffer, A. Schurmann, B. Lapauw, N. Rudovich, O. Pivovarova \& D. M. Ouwens (2018) The novel adipokine WISP-1 associates with insulin resistance and impairs insulin action in human myotubes and mouse hepatocytes. Diabetologia./

[5] Tacke, C., K. Aleksandrova, M. Rehfeldt, V. Murahovschi, M. Markova, M. Kemper, S. Hornemann, U. Kaiser, C. Honig, C. Gerbracht, S. Kabisch, T. Horbelt, D. M. Ouwens, M. O. Weickert, H. Boeing, A. F. H. Pfeiffer, O. Pivovarova \& N. Rudovich (2018) Assessment of circulating Wnt1 inducible signalling pathway protein 1 (WISP-1)/CCN4 as a novel biomarker of obesity. J Cell Commun Signal, 12, 539-548

[6] Klimontov VV, Bulumbaeva DM, Fazullina ON, Lykov AP, Bgatova NP, Orlov NB, Konenkov VI, Pfeiffer AFH, Pivovarova-Ramich O, Rudovich N. Circulating Wnt1-inducible signaling pathway protein-1 (WISP-1/CCN4) is a novel biomarker of adiposity in subjects with type 2 diabetes. J Cell Commun Signal. 2020 Mar;14(1):101-109

[7] Barchetta, I., F. A. Cimini, D. Capoccia, R. De Gioannis, A. Porzia, F. Mainiero, M. Di Martino, L. Bertoccini, M. De Bernardinis, F. Leonetti, M. G. Baroni, A. Lenzi \& M. G. Cavallo (2017) WISP-1 Is a Marker of Systemic and Adipose Tissue Inflammation in Dysmetabolic Subjects With or Without Type 2 Diabetes. J Endocr Soc, 1, 660-670..

[8] Ferrand N, Béreziat V, Moldes M, Zaoui M, Larsen AK, Sabbah M. WISP1/CCN4 inhibits adipocyte differentiation through repression of PPAR $\gamma$ activity. Sci Rep. 2017 May 11;7(1):1749.

[9] Berschneider B, Ellwanger DC, Baarsma HA, Thiel C, Shimbori C, White ES, Kolb M, Neth P, Königshoff M. miR-92a regulates TGF$\beta 1$-induced WISP1 expression in pulmonary fibrosis. Int $\mathrm{J}$ Biochem Cell Biol. 2014 Aug;53:432-41.

[10] Yang X, Wang H, Tu Y, Li Y, Zou Y, Li G, Wang L, Zhong X. WNT1inducible signaling protein-1 mediates TGF- $\beta 1$-induced renal fibrosis in tubular epithelial cells and unilateral ureteral obstruction mouse models via autophagy. J Cell Physiol. 2020 Mar;235(3):2009-2022

[11] Zhao X, Hua Y, Chen H, Yang H, Zhang T, Huang G, Fan H, Tan Z, Huang X, Liu B, Zhou Y. Aldehyde dehydrogenase-2 protects against myocardial infarction-related cardiac fibrosis through modulation of the Wnt/ $\beta$-catenin signaling pathway. Ther Clin Risk Manag. 2015 Sep 11;11:1371-81.

[12] Li X, Chen Y, Ye W, Tao X, Zhu J, Wu S, Lou L. Blockade of CCN4 attenuates CCl4-induced liver fibrosis. Arch Med Sci. 2015 Jun 19;11(3):647-53.

[13] Heise RL, Stober V, Cheluvaraju C, Hollingsworth JW, Garantziotis S. Mechanical stretch induces epithelial-mesenchymal transition in alveolar epithelia via hyaluronan activation of innate immunity. J Biol Chem. 2011 May 20;286(20):17435-44.

[14] Brown BA, Connolly GM, Mill CEJ, Williams H, Angelini GD, Johnson JL, George SJ. Aging differentially modulates the Wnt prosurvival signalling pathways in vascular smooth muscle cells. Aging Cell. 2019 Feb;18(1):e12844 